\title{
A LITERATURA INDÍGENA BRASILEIRA, O MOVIMENTO INDÍGENA BRASILEIRO E O REGIME MILITAR: UMA PERSPECTIVA DESDE DAVI KOPENAWA, AILTON KRENAK, KAKÁ WERÁ E ALVARO TUKANO
}

\author{
LENO FRANCISCO DANNER ${ }^{1}$ \\ UNIR
}

JULIE DORRICO ${ }^{2}$

$P U C-R S$

FERNANDO DANNER ${ }^{3}$

UNIR

\begin{abstract}
RESUMO: Tendo por base a postura de ativismo, militância e engajamento da literatura indígena, procuraremos refletir sobre a correlação de literatura indígena brasileira, movimento indígena brasileiro e a questão da ditadura militar, haja vista que a emergência e a consolidação público-políticas desse movimento indígena ocorreram exatamente no contexto da ditadura militar e como reação aos processos de expansão socioeconômica rumo ao centrooeste e ao norte do Brasil, promovidos e viabilizados por ela, situação que intensificou o etnocídio indígena. Nosso argumento central consiste em mostrar que podemos, a partir do estudo da literatura indígena, tomar conhecimento, pelo próprio relato autobiográfico, testemunhal e mnemônico dos indígenas, acerca de como sua situação social, que já era precária, foi piorada por tais projetos de expansão. Da mesma forma, esse estudo da literatura indígena também nos permite, em consequência, perceber o sentido e o direcionamento assumidos pelo movimento indígena no que tange a tais projetos, isto é, os povos, as lideranças e os intelectuais indígenas passaram a se organizar politicamente e a enraizar-se na esfera pública, política e cultural como forma de enfrentamento e de resistência a essa situação de etnocídio - sendo que a literatura por eles produzida é uma dessas ramificações do movimento indígena na esfera pública, política e cultural. E, assim, o estudo da literatura indígena nos
\end{abstract}

\footnotetext{
${ }^{1}$ Doutor em Filosofia pela PUC-RS. É especialista em teoria social (com especial ênfase em Teoria Crítica) e em filosofia política (Marx, Rawls e Habermas). Leciona filosofia e sociologia na Fundação Universidade Federal de Rondônia (UNIR). E-mail: leno_danner@yahoo.com.br .

2 Doutoranda no Programa de Pós-Graduação em Letras na Pontifícia Universidade Católica do Rio Grande do Sul; Pesquisadora na área da Literatura Contemporânea com ênfase na Literatura Indígena Contemporânea e autobiografia indígena. Pesquisadora do Grupo de Estudos em Teoria Política Contemporânea, sediado no Departamento de Filosofia Universidade Federal de Rondônia. E-mail: juliedorrico@gmail.com .

${ }^{3}$ Doutor em Filosofia (Pontifícia Universidade Católica do Rio Grande do Sul, 2011). Desde 2009, é Professor do Departamento de Filosofia da Universidade Federal de Rondônia (UNIR). Desenvolveu pesquisa pós-doutoral, na Université Paris I -Panthéon Sorbonne, sob supervisão do Professor Dr. Emmanuel Picavet. Membro do Grupo Démocratie et Participation - Groupement dInterêt Scientifique \&quot;Participation du Public, Décision, Démocratie Participative\&quot. E-mail: fernando.danner@gmail.com .
} 
permite ouvir a própria voz, a própria história dos indígenas por si mesmos, acerca de sua condição, de modo que a literatura indígena, em seu sentido aberto, anti-institucionalista, anticientificista e anti-tecnicista, lhes devolve a voz e o protagonismo estético-políticos.

PALAVRAS-CHAVE: literatura indígena; movimento indígena; ditadura militar; etnocídio; resistência.

ABSTRACT: Having as basis the activist, militant and engaged role of Indigenous literature, we we itend to correlate it with the Brazilian Indigenous movement and the period the country was under a military dictatorship, since the public-political emergence and consolidation of this Indigenous movement occurred exactly in the context of the military dictatorship, as a reaction to the process of social and economic expansion toward the midwest and north of Brazil, promoted and structured by that government - a situation that intensified Indigenous ethnocide. Our central argument is that we can learn, from the study of Indigenous literature, by Natives' own self-biographical, testimonial and mnemonic Indigenous history, about how their life conditions, which already were precarious, worsened because of those political projects of social-economic expansion. Consequently, the study of Indigenous literature also allows us to perceive the sense and the orientation assumed by Indigenous movement regarding such projects, that is, the Indigenous peoples, leaderships and intellectuals searched the political organization and rooted themselves in the public, political and cultural sphere as a reaction and resistance to this situation of ethnocide - and the literature made by Natives is one of these ramifications of the Indigenous movement in the public, political and cultural sphere. The study of Indigenous literature, therefore, enables us to listen the Natives' own voice, own history concerning their condition, so that Indigenous literature, in its open, anti-institutionalist, antiscientificist and anti-technicist sense, gives them an aesthetical-political voice and protagonism

KEYWORDS: Indigenous literature; Indigenous movement; military dictatorship; ethnocide; resistance.

Não vejo como dar um caráter educativo aos fatos e eventos que deram sentido à nossa luta, numa década cheia de protagonismos como foi aquela de 1970 e 1980, a não ser que possam ter interesse por conhecer essa fase da nossa história brasileira. Pois não se trata de história indígena, mas da sociedade brasileira se libertando da ditadura, com todas as consequências que isso representou para a sociedade como um todo: democracia, direitos humanos, justiça social, participação cidadã. Tudo isso foi criação desse período. Saímos da ditadura bruta, sem direito nenhum, para a invenção da democracia, com ampla participação dos povos todos: índios, negros, amarelos, azuis, cor-derosa, vermelhos... isso é uma coisa estonteante... Como passar isso para quem não viveu? Talvez fazendo literatura... (KRENAK apud MUNDURUKU, 2012, p. 83). 


\section{Considerações Iniciais}

Desde a década de 1990, os escritores, artistas e intelectuais indígenas têm articulado seus discursos políticos à publicização em livros, mídias ${ }^{4}$ e artes plásticas ${ }^{5}$. Queremos com isso dizer que o duplo pressuposto apresentado por tal perspectiva, da enunciação política e do discurso estético em sua profunda correlação e mútuo suporte, encontra na circulação e comercialização editorial vetores, instrumentos e caminhos para alcançar-se a sociedade não indígena. Nenhum dos polos: nem a perspectiva política, nem a postura estética, são polarizados, senão que compõem mutuamente a expressão indígena na contemporaneidade, o que significa que a produção literária indígena é, ao mesmo tempo, ativismo estético-político - arte como política, política por meio da arte. A literatura indígena, por exemplo, traz em sua narrativa a valorização da ancestralidade por meio da criação e da memória/histórias antigas e ancestrais, mas também a denúncia das violações contra os povos indígenas, ora de modo mais explícito, ora mais elíptico. De igual maneira, as artes plásticas e os veículos de comunicação gerenciados pelos próprios indígenas assumem um cunho e uma orientação diretamente promotores e fomentadores da condição e da causa indígenas, a fim de divulgar as culturas indígenas e o histórico opressivo sobre suas vidas e modos de viver, ontem e hoje.

As sociedades indígenas, portanto, aliam a transmissão de saberes tradicionais às tecnologias do presente para lutar contra a segregação, pelo direito à demarcação de terras, pelo direito à saúde, às escolas, às crenças e aos conhecimentos imemoriais-tradicionais. Nesse sentido, pensando nesse movimento circular de autoexpressão e resistência, argumentamos que a poética ameríndia no presente, desde o seu lugar de fala, utiliza ferramentas do "branco", como literatura, mídias e artes plásticas, para autoafirmação da alteridade, reiterar o orgulho do pertencimento e, nessa voz enunciativa, delatar de modo consciente as opressões históricas e as opressões do presente

\footnotetext{
4 Cf.: Rádio Yandê. Disponível em: <http://radioyande.com/>; Vídeo na aldeia. Disponível em: <http://www.videonasaldeias.org.br/2009/>; Hutukara. Disponível em: <http://www.hutukara.org>l. Acesso em 10 maio 2018.

${ }^{5}$ Denilson Baniwa protagonizou nesse ano de 2018, no Rio de Janeiro, a curadoria intitulada Terra Brasilis; $O$ agora não é pop. Disponível em: <http://www.centrodeartes.uff.br/eventos/terra-brasilis-o-agronao-e-pop/>. Acesso em 10 maio 2018.
} 
resultantes da neocolonização no país. Nessa conjuntura encontra-se a consciência da ditadura militar e seus efeitos agressivos para as comunidades tradicionais.

$\mathrm{Na}$ contramão do discurso do "progresso" e da "civilização", defendidos durante o período da ditadura militar (1964-1985), os autores indígenas recontam a história do país, em suas versões. Se a história oficial ainda não admite a memória ancestral e histórica dos povos indígenas como fundamento basilar para compor seus currículos, os escritores, artistas e intelectuais indígenas encontram na literatura, nas mídias e nas artes a forma por excelência para a transgressão desse discurso oficial. Este artigo, portanto, refletindo sobre a expressão estética no presente e as denúncias históricas contra os povos indígenas, elege três literaturas de intelectuais indígenas que realizam esse duplo movimento em suas obras, da estética para a política, da política para a estética; da tradição étnica, ancestral e comunitária para a crítica do presente, e desta para aquela: Davi Kopenawa e Bruce Albert com a obra A queda do céu: palavras de um xamã yanomami (2015); e Ailton Krenak, Kaká Werá e Álvaro Tukano, obras organizadas por Kaká Werá, Sérgio Cohn e Idjahure Kadiwel, que compõem a Coleção Tembetá (2017). Na primeira parte do texto, trataremos do conceito de literatura indígena e, assim, de como tais obras podem ser lidas sob o seu signo, isto é, sob a base e a dinâmica de uma literatura produzida pelos povos indígenas, desde si mesmos e por si mesmos; na segunda, apresentaremos a reflexão destes autores e intelectuais acerca da ditadura militar e dos seus efeitos, e como a adoção do discurso político, fundado na literatura, tornou-se a condição sine qua non para a articulação do movimento indígena na década de 1970 e das organizações indígenas na contemporaneidade.

Mas por que correlacionarmos literatura indígena e ditadura militar? Por dois motivos fundamentais, que também serão desenvolvidos ao longo desse texto e que, inclusive, possibilitam a compreensão dessa mesma literatura indígena como ativismo, militância e engajamento de uma voz-práxis estético-política profundamente vinculada ao movimento indígena brasileiro e que tem por dinâmica central a autoexpressão e a autoafirmação étnico-identitárias como crítica do presente. $O$ primeiro deles diz respeito ao fato de que o 
surgimento, a consolidação e o protagonismo do movimento indígena brasileiro têm sua gênese e seu mote exatamente no contexto da ditadura militar, como reação aos projetos políticos de desenvolvimento por ela fomentados, especialmente a expansão colonizatória, agrícola e mineradora no Centro-Oeste e no Norte do Brasil, situação que efetivamente ameaçou a existência dos povos indígenas nesse contexto, via tomada e expulsão de seus territórios, chacinas, doenças etc. $\mathrm{O}$ movimento indígena brasileiro, aqui, emerge como auto-organização dos povos indígenas e seu consequente ativismo público-político com vistas ao enfrentamento dessa situação, a partir da percepção de que o etnocídio-genocídio indígena somente poderia ser impedido por meio dessa organização política e em termos do ativismo, da militância e do engajamento público-políticos de que falamos acima. O segundo deles é que o consequente surgimento e desenvolvimento da literatura indígena brasileira, a partir do início da década de 1990, tem como foco a superação da invisibilização, do silenciamento e da exclusão culturais dos povos indígenas. Sua ideia central, conforme expressão dos próprios escritores e das próprias escritoras, é que os indígenas descobriram que precisavam falar diretamente à sociedade brasileira mais ampla, sem mediações institucionalistas, cientificistas e tecnicistas, de modo a que essa mesma sociedade brasileira ouvisse a própria voz desses povos, dessas lideranças e intelectuais.

Nesse sentido, a literatura indígena brasileira vincula-se ao movimento indígena brasileiro a partir de dois pressupostos fundamentais: (a) ela conjuga o agir diretamente na esfera pública, política e cultural e o falar diretamente à sociedade brasileira, enquanto uma perspectiva imbricada e mutuamente dependente, sob a forma de ativismo, de militância e de engajamento, que politizam e publicizam a questão indígena no país; e (b) ela busca, em termos estético-literários, o trabalho de desconstrução da história contada pelos brancos sobre o Brasil e os índios e de construção da hegemonia político-cultural, uma vez que, por meio dessa mesma literatura produzida e dinamizada pelos/as próprios/as intelectuais e escritores/as indígenas, se tem condições, como dissemos, de publicizar, de divulgar e de fomentar as tradições, as memórias, as histórias e, em tudo isso, a questão indígenas no país, ontem e hoje, tornando-a conhecida e enraizada 
institucional, educacional, cultural e politicamente - inclusive, o advento da Lei de Diretrizes e Bases da Educação Nacional, de 1996, viabilizou a realização de uma educação plural e calcada no trabalho com e no fomento das diferenças e das singularidades socioculturais brasileiras, em especial a situação e a alteridade-diferença dos povos indígenas. $O$ que queremos reconstruir e defender neste artigo, portanto, é exatamente a gênese e o ativismo do movimento indígena brasileiro como reação à ditadura militar, que são explicitados e tornados pungentes por parte da literatura produzida pelos/as próprios/as escritores/as indígenas do Brasil, o que aponta para esse sentido profundamente militante, ativista e engajado da voz-práxis estéticoliterária indígena, que é fundamentalmente vinculada, carnal e politicamente, acerca das bases de nossa sociedade, que fornece uma história alternativa de nossa constituição e de nossa evolução, a partir do próprio protagonismo das vítimas de nossa modernização conservadora, profundamente ligada e dinamizadora de uma ordem colonial autoritária, escravocrata, etnocida e dependente.

\section{A literatura indígena contemporânea: uma chave de leitura para Davi Kopenawa, Ailton Krenak e Álvaro Tukano}

A literatura indígena contemporânea é uma expressão artística enunciada pelos próprios indígenas, que se desenvolve com intensidade a partir da década de 1990 no Brasil. Tal enunciação caracteriza-se na apropriação de ferramentas como a escrita alfabética em língua portuguesa, a literatura e as mídias sociais, conjugando-as à língua materna, à oralidade e aos saberes ancestrais próprios aos povos indígenas. A produção material dos escritores indígenas, em caráter coletivo ou individual, ressignificada graças às suas especificidades culturais, portanto, caracteriza o consenso em torno desta expressão emergente e de matriz extraocidental.

Para Graúna (2013), a literatura indígena contemporânea pode ser lida em diferentes facetas que fogem ao enclausuramento do gênero e às limitações dos conceitos de conto, crônica e romance de ficção, principais formas do estatuto epistemológico da literatura 
ocidentalizada - o que significa que a literatura indígena funde, embaralha e apresenta um sentido mais amplo do que esse, inclusive e principalmente por correlacionar, por imbricar, arte, verdade e política, o que significa que a literatura indígena não é ficção enquanto história falsa, fantasiosa, como antítese da verdade e da objetividade científicas, mas exatamente relato verdadeiro, autoral, autobiográfico e mnemônico da condição indígena e, com isso, ativismo, militância e engajamento políticos. A autora retoma o conceito de auto-história, desenvolvido por Sioui (1989), para argumentar que a expressão indígena se configura na hibridez, e nela formula seu projeto literário. A auto-história engloba desde os ensaios, os textos autobiográficos, os artigos, os depoimentos, os relatos, as entrevistas, as cartas, as ilustrações, até os $e$-mails, e, ainda "outras formas de expressão que os (as) escritores (as) indígenas e descendentes utilizam para falar das diferenças culturais, imprimindo vez e voz aos seus personagens, à sua indianidade" (GRAÚNA, 2013, p. 70). Nessa perspectiva, a produção material dos autores indígenas não se restringe à publicação de livros, embora encontre nela seu maior alcance, senão que compreende a enunciação independente da forma em que se manifesta, seja no texto oral, escrito, ou em outras mídias e plataformas digitais. Em outras palavras, pode ser assumida como literatura indígena uma canção, um texto de blog, um depoimento, uma entrevista, um relato ou um texto autobiográfico além dos tradicionalmente conhecidos na forma de contos, crônicas, romances - desde que a alteridade indígena atue como protagonista.

$\mathrm{Na}$ definição realizada pelo teórico e literato indígena Daniel Munduruku (2017), a literatura indígena abrange diversas manifestações culturais, "como a dança, o canto, o grafismo, as preces e as narrativas tradicionais" (MUNDURUKU, 2017, p. 122). Tomada, na contemporaneidade, como instrumento de atualização da memória, a literatura indígena pode ser compreendida como escrita, falada, dançada ou cantada, pretendendo "informar a sociedade brasileira sobre sua diversidade social e linguística" (MUNDURUKU, 2017, p. 122). O conceito de literatura indígena transcende a escrita alfabética, posto que sua origem está na tessitura da oralidade e da ancestralidade transmitida de geração em geração. Essa alteridade, experienciada pelos autores conforme sua pertença étnica, consiste na base para a 
expressão estética, e envolve manifestações que vão desde performances até a produção de livros; ela também é a matéria para a resistência, vista na denúncia da violência histórica desde o contato com a sociedade não indígena. Os livros indígenas enfatizam este ou aquele aspecto étnico e/ou político de modo mais pungente, onde tal manifestação dependerá do processo e da intenção a que os escritores aspiram. Isto é, o projeto literário pode aparecer enfatizando a resistência política a que estão engajados os autores, narradores ou escritores, tais como Ailton Krenak, Davi Kopenawa e Álvaro Tukano, para o nosso caso aqui; ou ressaltar o caráter criativo-estético das narrativas míticas que aparecem sob a forma de "contação de histórias", como em livros de Daniel Munduruku, Eliane Potiguara, Cristino Wapichana, Yaguarê Yamã, entre outros. Entretanto, em ambos os casos, que geralmente aparecem interligados, o objetivo é o mesmo: apresentar à sociedade a perspectiva autoral, ativista e direta dos/as próprios/as indígenas, para além das descrições extemporâneas, caricatas e tecnicistas feitas deles e sobre eles por não-indígenas. Esse, por exemplo, é o objetivo da produção estético-literária de Daniel Munduruku, que ele não desliga e não desvincula da busca por hegemonia político-cultural dos e pelos povos indígenas. Contando-nos sobre seu ativismo e sua militância como escritor indígena, sobre o mote normativo dessa sua produção estético-literária, ele nos diz:

Num dia qualquer, uma menininha quis saber onde ela poderia encontrar as histórias que eu contava para que pudesse ler. Aquela pergunta me pegou de "calças curtas", como se diz. Eu não poderia dizer a ela a bibliografia da USP e nem soube indicar os livros que continham as histórias. Na verdade, fiquei sem resposta. Dias depois, fui a uma grande livraria da cidade e pedi para o vendedor me mostrar onde estavam os livros para crianças que tratavam da temática indígena. Ele me apresentou uma prateleira que trazia uma plaquinha escrita: folclore. Mesmo achando estranha a descrição, fui olhando título a título. Encontrei vários livros abordando o tema, mas nenhum deles escrito por indígenas. Boa parte era mesmo narrativa folclórica dos personagens já conhecidos. Vez ou outra, encontrei alguns títulos que narravam histórias e traziam informações sobre os povos de onde tinham sido extraídas. A maioria, no entanto, repetia a visão 
estereotipada e excludente, fazendo os leitores acreditar que os povos indígenas eram coisa do passado. Eu tinha que procurar reverter esse quadro. Não era justo que nossos povos figurassem como folclore nas prateleiras, como se fossem personagens de um passado que não existia mais (MUNDURUKU, 2016, p. 172-173).

Nota-se, portanto, como específico do ativismo estético-literário indígena, a necessidade de politização e de publicização dos indígenas por si mesmos e desde si mesmos, o que, como dissemos, vincula arteliteratura, política e/como crítica, reflexividade e objetividade. Em verdade, a matriz da literatura indígena destaca 0 caráter "extraocidental" de seus textos, temas e princípios - e autores/as, evidentemente (MEDEIROS, 2006). Ela se funda nos saberes ancestrais e é guiada pela cosmovisão ameríndia; contudo, nesse sistema literário indígena emergente, observamos que ela dialoga de modo intercultural com estruturas modernas, a fim de reivindicar um lugar na sociedade brasileira para si e para os povos indígenas. Em outras palavras, a literatura dos escritores indígenas articula-se na conjugação da educação tradicional e formal, buscando valorizar sua ancestralidade. Além disso, está inserida no circuito editorial, momento em que o comércio de editoras se volta para a produção indígena, e também no âmbito conceitual, posto que se apropria de conceitos como literatura, ficção, gêneros, ressignificando-os ao modo indígena. Tais apropriações conceituais são compreensíveis, pois a literatura nasce no bojo da educação escolar indígena com a experiência da autoria coletiva, como afirmam Almeida e Queiroz (2004). Thiél (2012), de sua parte, observa que "no século XX, o índio resiste e se expressa por meio de uma produção literária crescente e enriquecedora, apesar de sua voz não significar presença para o colonizador em séculos anteriores" (p. 35). Como estamos argumentando, a novidade da literatura indígena está exatamente na sua profunda intersecção e no seu alinhamento direto ao movimento indígena, como sua ferramenta normativa, garantidora de hegemonia político-cultural. É a voz dos oprimidos tornando-se obra, reflexivizando e politizando nossa sociedade, suas estruturas, suas instituições, seus sujeitos sociopolíticos, suas relações e seus valores fundamentais - por isso, inclusive, que utilizamos ao longo do texto, em variadas ocasiões, o conceito de voz-práxis para indicar uma produção 
autoral catártica, autoafirmativa, reflexiva e politizada sobre si e sobre a sociedade em que os indígenas estão inseridos.

Para Graúna (2013), escritora e intelectual indígena, o contorno dessa produção se dá em dois segmentos: na literatura indígena do período clássico, "referente à tradição oral (coletiva) que atravessa os tempos com as narrativas míticas" (p. 74); e a do período contemporâneo,

(de tradição escrita individual e coletiva) na poesia e na 'contação de histórias' com base em narrativas míticas e no entrelaçamento da história (do ponto de vista indígena) com a ficção (em fase de experimentalismo) (GRAÚNA, 2013, p. 74).

A classificação da autora evidencia características em realce na produção dos escritores contemporâneos, tanto na prosa quanto na poesia: a ancestralidade, ou as narrativas míticas, entrelaçada à história e à ficção. A história, aqui, refere-se à versão contada a partir dos indígenas, e não àquela que se inscreve nos manuais oficiais didáticos uma história não necessariamente linear que imbrica tempo mítico e movimento histórico, protagonismo pessoal e condição coletiva, etc. E a ficção, nesse seguimento, trata do caráter criativo (na linguagem, na forma, no conteúdo, no sentido) do autor, cuja obra, conforme argumenta Graúna (2013), não escapa desse inevitável entrelaçamento. Podemos dizer, desse modo, que a literatura indígena, apresenta em suas obras a conotação e a denotação. Com efeito, a criação do autor está embebida na memória coletiva, ao mesmo tempo em que possibilita a enunciação do sujeito indígena e, em tudo isso, vai da tradição à crítica do presente, usando a memória étnico-identitária como crítica do presente, como base para a apresentação da singularidade e como núcleo da denúncia da violência histórica vivida e sofrida pelos povos indígenas.

Graúna (2013) argumenta, a propósito, que a propriedade intelectual do sujeito indígena não está dissociada da noção coletiva, de sua pertença étnica. Reconhecer essa presença duplamente imbricada nos livros indígenas de autoria individual significa exercitar o respeito em relação aos indígenas e sua arte. Por isso, quando pensamos as obras de autoria individual publicadas na contemporaneidade, 
propomos o conceito do eu-nós lírico-político. O conceito formulado reconhece o protagonismo dos sujeitos indígenas (eu) em sua enunciação discursiva e também o caráter coletivo-étnico (nós) que os autores trazem para as camadas de significações de seus textos. De igual modo, reconhece o duplo movimento de autoexpressão (lírica) potencializada por meio da arte, e de resistência (política), vista nas denúncias da violência histórica desde o colonialismo até os dias de hoje. Nesse sentido, a literatura indígena é marcada por um eu-nós lírico-político em que o/a escritor/a de antemão está comprometido/a e ligado/a à comunidade ou ao grupo em questão, não podendo elidir essa pertença radical, como de resto qualquer literatura de minorias o/a escritor/a de minorias é e representa, com seu lugar de fala, com seu ativismo, o grupo a que pertence. Esse, aliás, como veremos adiante, é mais um ponto importante para entendermos a profunda imbricação entre movimento indígena e literatura indígena brasileira, exatamente por essa percepção, própria às culturas indígenas, da ligação umbilical entre comunidade e indivíduo, que não anula nem aquela e nem este, antes pelo contrário, os promove de modo concomitante (uma vez que, no Ocidente, o indivíduo liberal desengajado e desvinculado é uma ilusão, não se sustentando na prática) (cf.: Munduruku; Werá; Tukano; Krenak; Kopenawa e Albert).

$\mathrm{Na}$ esteira da classificação realizada por Graúna (2013), encontramos a de Behr (2017). A autora sistematiza três momentos que caracterizam a autoria da literatura indígena: a narração de mitologia, a literatura que emana de projetos pedagógicos e a produção de escritores indígenas autoproclamados (BEHR, 2017, p. 272-275). O primeiro momento trata da transcrição de mitos como adaptação escrita de relatos orais, realizada por viajantes, cientistas e antropólogos. A concentração está nos relatos mitológicos, mas, aqui, os narradores desses mitos indígenas não figuram como autores de suas narrativas, e sim como informantes dela. O protagonismo em termos de autoria pertence aos organizadores, os tradutores e organizadores dessas coletâneas, sendo que os contadores de histórias indígenas ficam em segundo plano, em uma situação, em muitos casos, periférica.

O segundo momento refere-se à produção realizada pelas escolas indígenas, cuja conquista se assenta nos direitos assegurados pela 
Constituição Federal de 1988, que reconhece o direito à educação diferenciada para os povos indígenas. Manufaturada para ser utilizada nas escolas, a autoria indígena possui caráter coletivo. Isto é, se antes os indígenas eram tidos como informantes/colaboradores de suas narrativas, agora passam a operar de modo direto na confecção de seus livros junto à comunidade, sendo que, como consequência, a autoria passa a ser coletiva, ligada ao povo em questão. Behr (2017) afirma que "o sujeito principal da narração é o 'nós', que representa o autor coletivo, a comunidade em seu conjunto" (p. 269). Embora o processo da autoria coletiva conte com a participação de sujeitos não indígenas, a sua tônica reside na identidade indígena e o referencial é o sujeito coletivo, destacando o processo de autonomia em que estão envolvidos os indígenas e a sua comunidade. O terceiro momento, por fim, desenvolve a atuação de escritores individuais que se autodenominam indígenas envolvidos no processo de publicação de livros com editoras privadas. Tais escritores dotam-se de reivindicações políticas, como argumenta a autora, posto que "lutam para se reapropriar de tradições e relatos indígenas e fazer com que a herança indígena seja também reconhecida" (Behr, 2017, p. 277). Todavia, não obstante a luta, estes autores, apesar de publicados e começarem a ser conhecidos, "não receberam consagração, nem grande prêmio literário, e permanecem à margem das academias de literatura" (BEHR, 2017, p. 271). Podemos argumentar, entretanto, que a produção desses escritores indígenas passa a ser tomada como referencial nos circuitos literários, recebendo também muitas premiações. A título de exemplo, dois escritores indígenas foram premiados, no ano de 2017, no $59^{\circ}$ Prêmio Jabuti 6 , evento que reconhece a qualidade e o trabalho dos escritores que nele concorrem. Daniel Munduruku e Cristino Wapichana, que são esses escritores indígenas acima mencionados, foram premiados nessa mesma edição. No que tange, porém, à ausência dessa produção nos currículos dos cursos de letras, percebemos que, apesar da Lei $11.645 / 2008$ normatizar a necessidade do ensino das culturas indígenas nos cursos de letras, história e artes, tal prática é, ainda,

\footnotetext{
${ }^{6}$ Daniel Munduruku e Cristino Wapichana recebem em 2017 o Prêmio Jabuti com as respectivas obras Vozes Ancestrais e A boca da noite. Ver on-line: <http://premiojabuti.com.br/apuracao/f2-dt311017$1507 />$.
} 
infelizmente, basicamente teoria, não tendo se consolidado. Desde a narração de mitos em que os indígenas eram tidos apenas como informantes, passando pela autoria coletiva até a autoria individual, a produção autoral dos sujeitos indígenas cresceu desde a década de 1990. Esse mercado diverso e múltiplo da literatura indígena reúne todas essas manifestações, sem prejuízo de anular o ativismo e a expressão estética desses sujeitos na contemporaneidade.

É o caso, por exemplo, da obra $A$ queda do céu: palavras de um xamã yanomami, cuja autoria é compartilhada entre o antropólogo Bruce Albert e o xamã yanomami Davi Kopenawa. Se o primeiro organiza o relato oral e o escreve, é ao segundo, pertencente ao povo yanomami, que pertence a cosmologia que com vigor compartilha, resultando no projeto que é a obra. De igual modo, podemos assinalar as obras Ailton Krenak e Álvaro Tukano, que carregam os mesmos nomes das lideranças indígenas. Tais obras integram a coleção Tembetá, que, como indica no prefácio escrito por Kaká Werá, busca publicizar a trajetória de pensadores indígenas do Brasil que têm contribuído para a cultura, a educação, os direitos humanos e a ecologia nos últimos quarenta anos. Em formato de entrevista e de textos curtos, de intervenções pontuais, estes projetos literários enfatizam a trajetória política destes intelectuais que abordam a resistência política desde o movimento indígena na década de 1970 às manifestações artísticas, sempre enfatizando o relato, a denúncia e o combate à opressão histórica perpetrada sobre eles. A leitura das obras a seguir será compreendida e dinamizada como literatura indígena, posto que, como observa Graúna (2013), tem por base o protagonismo da alteridade indígena. Se, por um lado, elas fogem à convencionalidade da literatura ocidentalizada, por outro, elas apresentam as vozes dos indígenas em resistência, que buscam, por meio da escrita e da publicação, denotar sua cultura, em termos críticos e literários próprios ao modo indígena. É nesse sentido que, por exemplo, Kaká Werá define a literatura indígena como instrumento político utilizado e reestilizado pelos próprios povos indígenas para a afirmação de suas tradições e para o desenvolvimento e a publicização de suas histórias, de suas memórias. É um instrumento político porque (a) explicita a própria voz dos/as escritores/as e intelectuais indígenas, (b) permite-lhes o relato direto, autobiográfico, testemunhal e 
mnemônico da sua singularidade e da sua condição de vítimas de nossa modernização conservadora, bem como (c), em tudo isso, possibilita a consolidação da cidadania indígena via protagonismo estético-literário em termos de ativismo, de militância e de engajamento políticoculturais. Vejamos o que ele nos diz sobre isso:

Para nós, a literatura indígena é uma maneira de usar a arte, a caneta, como uma estratégia de luta política. É uma ferramenta de luta. E por que uma luta política? Porque, à medida que a gente chega na sociedade e a sociedade nos reconhece como fazedores de cultura, como portadores de saberes ancestrais e intelectuais, ela vai reconhecendo também que existe uma cidadania indígena (WERÁ, 2017, p. 29; destaques do autor).

Em suma, a literatura indígena tem seu sentido na autoexpressão estético-criativa, dando voz e vez ao indígena, que se utiliza de sua voz-práxis como forma de promoção e de fomento de sua matriz étnico-cultural, de sua singularidade antropológica, bem como enquanto instrumento político, como forma de denúncia e de politização das situações de marginalização e exclusão por ele vividas e sofridas, como relato das vítimas por si mesmas e desde suas experiências acerca de nossa história, de nossa modernização conservadora. Este último caso é, neste artigo, o núcleo paradigmático da literatura indígena como ativismo, militância e engajamento: os escritores indígenas aqui estudados aliam-se diretamente ao movimento indígena brasileiro (que eles mesmos ajudaram a criar) e têm como objetivo colocar a produção estético-literária como instrumento e como história da condição indígena no Brasil, como veremos nesta segunda seção, a partir da relação entre literatura indígena, movimento indígena e ditadura militar. Se o movimento emerge, se desenvolve e se consolida pública e politicamente, a literatura indígena encontra seu sentido exatamente na busca pela hegemonia político-cultural desse mesmo movimento, em termos de publicização e de fomento da questão indígena no país. Em ambos os casos, é o ativismo, a militância e o engajamento diretos que os definem, bem como sua correlação e mútuo sustento. 
O movimento indígena, a literatura indígena e a ditadura militar: notas sobre a emergência e o desenvolvimento do ativismo indígena

O movimento indígena brasileiro emerge, desde meados da década de 1970, como uma reação de povos, lideranças e intelectuais indígenas contra o processo de expansão socioeconômica dinamizado pelos governos militares em relação às regiões Centro-Oeste e Norte do Brasil, que levou à expulsão de muitos povos indígenas de suas terras, a alterações em seu habitat (desmatamento, mineração, aniquilamento de aldeias, etc.), à perseguição e à matança desenfreadas deles, e ao surgimento de problemas sanitários e sociais nas comunidades indígenas (doenças, processos de desestruturação social e de descaracterização cultural etc.) que geraram situações de etnocídio entre esses povos, levando muitos deles à quase extinção (cf.: VALENTE, 2017). Conforme podemos perceber nos testemunhos de lideranças e de intelectuais indígenas que viveram nesse contexto, essa situação de etnocídio permanente, praticamente normalizada pelos governos militares (e civis, ligados a estes), de um etnocídio feito em nome do progresso civilizacional e do desenvolvimento socioeconômico, de um etnocídio conduzido tecnocraticamente, passou a representar para os povos indígenas um verdadeiro desafio político, cujo enfrentamento era absolutamente necessário como condição da sobrevivência física e cultural desses mesmos povos. Foi exatamente esse o mote político que esteve na base do - e que dinamizou o - surgimento do movimento indígena brasileiro ao longo dos anos 1970. Conforme Ailton Krenak, um dos criadores e uma das lideranças articuladoras do movimento, foi como reação à condução tecnocrática desse processo de etnocídio, feita em nome do progresso, da expansão e do desenvolvimento socioeconômicos, que povos, lideranças e intelectuais indígenas de diferentes nações uniram-se política e culturalmente em torno ao movimento indígena, alçando-o ao status de sujeito, causa e condição público-políticos. Ele diz:

As pessoas se perguntam o que tanta gente diferente que se encontrou naquele momento, índios de diversas etnias, ribeirinhos, seringueiros, podiam ter em comum. O que tinha em comum era o medo do progresso! No nosso caso, muito mais do que isso, era o medo do 
branco. Mas não de um branco qualquer. Existe todo um esquema, um acúmulo de capital... O índio achou que não sobreviveria a isso. Eu já me perguntei se íamos conseguir sobreviver a isso (KRENAK, 2015, p. 220).

No caso, a percepção política basilar que dinamizou a construção e o ativismo desse movimento indígena consistiu exatamente em que os povos indígenas, suas lideranças e seus/suas intelectuais deveriam assumir uma perspectiva de militância e de engajamento públicopolíticos, de que eles deveriam consolidar-se como sujeitos, causa e condição público-políticos enquanto o núcleo para o enfrentamento dessa condução tecnocrática de tais processos de etnocídio como consequência da expansão socioeconômica desregulada perpetrada pelos governos militares. De fato, aqui, a superação do privatismo, do silenciamento e da invisibilização público-políticos aos quais os povos, as lideranças e os/as intelectuais indígenas estavam submetidos/as, via voz-práxis ativista, militante e engajada dos indígenas por si mesmos e desde si mesmos, seria a solução, a única solução, em verdade, para o enfrentamento desses processos tecnocráticos de etnocídio/genocídio. O movimento indígena brasileiro, por conseguinte, marca a entrada dos povos indígenas, de seus/suas intelectuais e de suas lideranças na esfera público-política e como sujeitos público-políticos, que dinamizam sua voz e que tornam pungente sua ação frente às instituições, buscando tornar-se interlocutores privilegiados da questão indígena, sempre que ela se torna ponto e problema fundamentais para a constituição e para a evolução da sociedade brasileira. É nesse sentido que Ailton Krenak considera a década de 1970 como um marco para a história da sociedade brasileira de um modo geral e para os povos indígenas em particular, porque, por meio do movimento indígena brasileiro, nós temos a entrada em cena na esfera público-política e como sujeito público-político de um novo protagonista, até então marginalizado e periferizado política, cultural, institucional e epistemologicamente, os indígenas como sujeitos, causa e condição políticos. Não por acaso, para Ailton Krenak, a emergência do movimento indígena representa a segunda descoberta do Brasil, a mais fundamental para os rumos da política, da cultura e das instituições brasileiras contemporâneas. Diz Krenak: 
Eu acho que teve uma descoberta do Brasil pelos brancos em 1500 e, depois, uma descoberta do Brasil pelos índios nas décadas de 1970 e 1980. A que está valendo é a última. Os índios descobriram que, apesar de eles serem simbolicamente os donos do Brasil, eles não têm nenhum lugar para viver nesse país. Terão de fazer esse lugar existir dia a dia. Não é uma conquista pronta e feita. Vão ter que fazer isso dia a dia, e fazer isso expressando sua visão do mundo, sua potência como seres humanos, sua vontade de ser e de viver (KRENAK, 2015, p. 248).

Ora, em que sentido, por que o movimento indígena representourepresenta uma segunda descoberta do Brasil? Exatamente porque, como dissemos acima, ele leva à consolidação dos povos indígenas, de suas lideranças e de seus/suas intelectuais como sujeitos, causa e condição público-políticos, como protagonistas, epistemológica, política e culturalmente falando, de sua história, como construtores, em termos de cidadania político-cultural, da própria história, do presente de nossa sociedade. O movimento indígena brasileiro, por conseguinte, institui, funda e dinamiza o ativismo, a militância e o engajamento públicopolíticos dos povos, das lideranças e dos/as intelectuais indígenas na esfera pública, como sujeitos públicos, políticos e culturais, permitindo a superação do silenciamento, da invisibilização e do privatismo a que estavam submetidos. Conforme destaca Alvaro Tukano, outra liderança fundamental do movimento indígena brasileiro, que contribuiu fortemente para sua fundação e para seu protagonismo, o enfrentamento do etnocídio institucionalizado e normalizado como política de Estado e como base da expansão e da integração socioeconômicas de nossa sociedade, com a consequente organização desse movimento indígena, teve por meta a desconstrução do paternalismo tecnocrático imposto aos povos indígenas pela conjugação da ditadura militar, de instituições políticas e de organizações religiosas, que tratavam os indígenas como povos e sujeitos menores, de responsabilidade relativa. Com o movimento indígena brasileiro e por meio dele, tratava-se, por conseguinte, de dar voz e vez aos próprios povos indígenas, às suas lideranças e aos/às seus/suas intelectuais. Segundo Alvaro Tukano: 
Tem muitas histórias de militares que nós podemos ler nas crônicas de como foi a expansão colonial na região Norte. E os missionários sempre estiveram ao lado deles. O missionário é aquele que faz o voto de castidade, o voto de pobreza, mas tem suas falhas. Eu sou crítico à falta de ética dos missionários. Eles fazem voto de castidade, voto de pobreza, mas são humanos, erram. Então essa é a confusão que nós podemos enxergar melhor. E os missionários possuem os seus aliados. Aliados dos missionários: onde eles estão? Eu, como simples observador, onde tem um general, tem um cardeal, um ministro. Isso não foi diferente no Rio Negro. Os inimigos são esses... E eu não vi nenhum general matar o índio com uma espingarda não, mas houve uma aliança entre a Igreja e o Estado para poder nos aculturar. Aculturar é introduzir a educação para o índio falar português, deixar de ser índio. Então, esse foi o processo que ocorreu no Rio Negro (TUKANO, 2017, p. 16-17, destaques nossos).

Note-se para a ênfase que demos, na passagem acima, para o termo "confusão que nós podemos enxergar melhor". Os indígenas podem relatar melhor, explicar melhor essa situação de descaracterização e de colonização político-culturais levada a efeito nesse contexto da ditadura militar e em termos de associação entre Estado, instituições públicas (como o SPI e, depois, a FUNAI) e instituições religiosas católicas e evangélicas - uma descaracterização tecnocrática, conforme o estamos mencionando (cf.: VALENTE, 2017, p. 10-11). Aqui, em consequência, o falar diretamente e o agir politicamente sem mediações institucionalistas, cientificistas e tecnicistas seriam o caminho e o instrumento para o enfrentamento dessa tutela tecnocrática de tais instituições em relação aos povos indígenas. Nesse sentido, o movimento indígena brasileiro (assim como, depois, a literatura indígena na esteira dele) institui uma voz-práxis direta, política e politizante, carnal e vinculada dos indígenas por si mesmos e desde si mesmos, em que a tutela tecnocrática seria substituída pelo ativismo, pela militância e pelo engajamento públicopolíticos do sujeito indígena. Alvaro Tukano diz:

Para mim, é muito bonito falar para os jovens que dependemos dessa terra, dependemos dos frutos da terra, das águas. Então é por isso que a gente quer a nossa comunicação com os estudantes e universitários. 
Seja índio ou branco, a gente tem de fazer uma nova sociedade. O Brasil precisa ser dirigido pelos novos, menos contaminados por essa prática de evangelizar e de tutelar o índio. Se a tutela fosse uma salvação de fato, eu bateria palmas. Mas tem limitado a minha voz, tem atado as minhas mãos e de outros líderes também. Então, o que estou falando é para desatar esse pano que tem vendado as vozes das lideranças, as mãos das lideranças. Acho que o público tem de ouvir diretamente o que os verdadeiros líderes pensam, falam e defendem sobre a questão indígena. É isso que se tem que entender (TUKANO, 2017, p. 26).

Note-se a ênfase, por parte de Alvaro Tukano, na necessidade de se falar diretamente, de se agir sem mediações, ou seja, na importância que a própria voz e a própria práxis dos povos, das lideranças e dos/as intelectuais indígenas se faça presente e se consolide na esfera públicopolítica, uma vez que, obviamente, eles/elas são os sujeitos privilegiados quando o ponto central é exatamente a questão indígena (mas não só, evidentemente, posto que os assuntos políticos são uma prerrogativa de todos/as e para todos/as os/as cidadãos/cidadãs). Isso exigia e exige a permanente desconstrução desse paternalismo tecnocrático de que estamos falando, para o qual os povos indígenas, dada sua constituição pré-civilizacional, não têm condições de inserirse em igualdade de condições e com o mesmo protagonismo na esfera pública, política e cultural. Acerca disso, é importante mencionar-se que o mote fundador e dinamizador do movimento indígena brasileiro, isto é, o enfrentamento do paternalismo tecnocrático por meio da constituição de uma voz-práxis ativista, militante e engajada em termos públicos, políticos e culturais, teve por meta combater e transformar uma condição que sempre acompanhou a compreensão e o enquadramento hegemônicos sobre esses mesmos povos indígenas, a saber, de que eles seriam sujeitos relativos, povos menores, sem capacidade ou com pouca capacidade de tornar-se cidadãos e cidadãs, civilizados e civilizadas. Diga-se de passagem, a crítica, a desconstrução e a transformação da responsabilidade relativa dos povos indígenas perspectiva ideológica construída pelos colonizadores e que justificava o paternalismo tecnocrático - foi encampada pelo movimento indígena brasileiro ao longo de toda a década de 1970 e de 1980, somente sendo eliminada na Constituição Federal de 1988 (que contou com a 
participação de lideranças indígenas e que levou ao chamado Capítulo dos índios CF/88, Arts. 231-232). Combater a tutela e o paternalismo tecnocráticos, por conseguinte, exigiu a crítica, a desconstrução e a transformação da responsabilidade relativa que deslegitimava os povos, as lideranças e os/as intelectuais indígenas como movimento, sujeito, causa e condição público-políticos. Diz Ailton Krenak sobre esse ponto fundamental que dinamizou o ativismo do movimento indígena ao longo dos anos 1970 e 1980:

A responsabilidade relativa não tem a ver comigo. Ela tem a ver com os outros. Meu avô viveu até 96 anos. Meu avô criou o meu pai, todos os meus tios e os netos. E para o governo ele continuava sendo alguém com responsabilidade relativa. Para o meu povo, meu avô foi um sábio, um guerreiro. Para o governo brasileiro, ele foi um menino, um sujeito que devia ser vigiado, tutelado. Mas nós podemos observar também que a sociedade brasileira, apesar de já ter aí uns 200 ou 300 anos de vida institucional, continua sendo considerada pelo Estado algo parecido. Uma espécie de deficiente mental. Então acho que nós podemos concluir que isso diz menos respeito ao nosso espírito e ao nosso propósito no mundo e muito mais a uma visão que os outros têm de nós mesmos. [...] Eu voto. Pratico vários atos jurídicos que os brasileiros têm o prazer de fazer. $E$ meus parentes, que não exercitam esses chamados direitos civis, são também cidadãos, porque ninguém é mais cidadão na América do que os nossos antigos. Se cidadania se mede por gestos cívicos como votar, tirar cédula de identidade ou coisas assim, nós não somos cidadãos. Mas se ser cidadão é você estar instalado numa região, num lugar onde você participa, onde você vive, nós somos os primeiros cidadãos aqui da América. Acho que a maioria das pessoas tem dificuldade de nos considerar remanescentes de uma guerra de colonização. Todos os meus parentes são remanescentes de uma guerra de ocupação. Quando os seus parentes vieram para cá, involuntariamente se instalaram como forças de ocupação da minha terra. Acredito que a grande maioria veio sem saber o que estava fazendo. Os que vieram sabendo o que estavam fazendo e os que vieram sem saber estavam realizando a ocupação dos nossos territórios. Hoje, se a minha tribo está reduzida a quase uma centena de indivíduos, sendo que no começo do século $(X X)$ nós éramos mais de 5 mil pessoas, e se o nosso território atual é uma reserva mineral de 4 mil hectares, isso tem de ser compreendido como parte de 
minha história, muito mais do que uma cédula de identidade. A minha história de maneira nenhuma se resume ao conjunto de documentos públicos que 0 governo me deu (KRENAK, 2015, 83-84).

Vemos, portanto, na passagem acima, que o ativismo, a militância e o engajamento público-políticos dos indígenas por si mesmos e desde si mesmos, com a consequente dinamização de uma voz-práxis direta, sem mediações, participativa e inclusiva, inverte o ônus da prova sobre essa perspectiva tecnocrática (e cultural) assumida pelos governos militares, ao mesmo tempo em que confere protagonismo políticocultural aos próprios indígenas: de um lado, ela exige que as instituições provem em que sentido o indígena é portador de responsabilidade relativa, se é que já podem fazê-lo, dado esse ativismo público-político pungente, sem misericórdia para com as situações de marginalização sofridas pelos povos indígenas; de outro, mas concomitantemente, ela permite a crítica, a reflexividade e a desconstrução permanentes da sociedade brasileira, de seu passado, de seu presente e de seu futuro, por meio do protagonismo indígena em termos públicos, políticos e culturais. Nesse aspecto, a responsabilidade relativa dos indígenas, assumida pelas instituições público-políticas tecnocráticas e consolidada sob a forma de preconceito cultural, pelas nossas elites e em termos de modernização conservadora, é um reflexo de uma questão muito maior, que a ditadura militar exemplifica à perfeição, a saber, de que é o povo brasileiro, na visão de nossas elites e de nossas instituições tecnocráticas, que possui responsabilidade relativa, e não apenas os povos indígenas, porque, no fim das contas, um golpe político-militar somente se justifica por causa da responsabilidade relativa do povo que os golpistas buscam conduzir, libertar, salvar! Por outras palavras, em uma sociedade ainda marcada por fortes ranços do colonialismo reproduzidos em termos de nossa modernização conservadora, não apenas os indígenas, mas também todo povo brasileiro é percebido e afirmado - e às vezes se percebe e se afirma - como tendo responsabilidade relativa, como dependendo da chibata e do fuzil para colocar-se em ordem. Nesse aspecto, é por causa do potencial político e cultural explosivo que os povos indígenas representam, uma vez atuantes na esfera público-política, como 
sujeitos público-políticos, que a tutela e o paternalismo tecnocráticos Ihes são impostos como ideologia e prática político-culturais da colonização. É ainda Ailton Krenak quem nos fala. À pergunta de "Por que o governo mantém os indígenas tutelados?", ele diz:

Acho que você conhece a história das potências que colonizaram outras regiões do mundo e que tratam os nativos como cidadãos de segunda ou terceira categoria. Se você observar, a Inglaterra e a França mantinham até recentemente colônias na África e na Ásia, onde os nativos tinham o status aproximado da mula ou do cavalo. Aqui, no Brasil, os índios continuam tendo um status parecido com o de animais silvestres. Nós somos objetos da atenção do Estado enquanto seres que precisam ser preservados como fauna. Também temos a atenção do Estado como pessoas e indivíduos que precisam ser vigiados para que não entrem num processo de contestação do poder do Estado, de contestação da ordem estabelecida e de questionamento dos crimes que foram praticados contra o nosso povo. Nós somos a memória viva e um testemunho sempre muito explícito da história recente da ocupação desta região do mundo. Cada um dos nossos meninos sabe como foi que os brancos se tornaram senhores desta terra e quando nós deixamos de ser os donos (KRENAK, 2015, p. 85-86).

Queremos chamar a atenção para a afirmação, por parte de Ailton Krenak, de que os povos indígenas são um testemunho vivo e uma memória sempre presente e atualizada acerca da história e da evolução de nossa sociedade brasileira, uma vez que foram as vítimas mais pungentes delas, juntamente com o povo negro. Ora, e em que sentido se pode ser testemunho vivo e memória sempre presente e atualizada de nosso processo societal-cultural-institucional? Em que sentido se pode ser história viva da constituição e da evolução de nossa sociedade? Exatamente no momento em que se dinamiza uma fala-práxis direta, sob a forma do ativismo, da militância e do engajamento públicopolíticos, que superam a invisibilização, o silenciamento e o privatismo, que desconstroem a tutela, o paternalismo e a menoridade tecnocráticos (e culturais). Somente se pode ser um testemunho e uma história vivos e uma memória pungente e atualizada quando se participa como cidadãocidadã, como movimento social na esfera público-política, quando se 
assume protagonismo cultural. É aqui que podemos situar, conforme estamos argumentando ao longo do texto, o núcleo epistemológico, político e normativo assumido pela literatura indígena brasileira que emerge e que se consolida a partir dos anos 1990 em profunda imbricação e dependência para com o movimento indígena: seu objetivo, como dissemos ao longo do texto, como vimos acima pela passagem de Daniel Munduruku, consiste em falar e agir diretamente na esfera público-política em busca de hegemonia cultural, agora com o objetivo de construir perspectivas alternativas sobre os povos indígenas, não mais caricatas, tecnicistas e nem extemporâneas, mas autorais, calcadas na própria singularidade e dinamizadas sob a forma de relato da condição de marginalização, de exclusão e de violência. Sobre esse núcleo normativo-político da literatura indígena em termos de ativismo, de militância e de engajamento, que a aproxima e a imbrica ao movimento indígena, diz Kaká Werá:

Naquela mesma época, em nossos encontros na aldeia Guarani, eu conversava muito com o Daniel Munduruku. Ele já era um educador, formado em filosofia, e dava aula em escola pública. A gente conversava sobre como encontrar maneiras de potencializar esse trabalho de difusão. E tanto ele quanto eu gostávamos muito de literatura. Eu já estava ensaiando meus primeiros escritos literários. Então nós sonhamos, naquela época não era ainda criar um movimento de literatura indígena, mas em usar a escrita para falar das nossas culturas. Para falar diretamente. Para se ter uma ideia, até o início dos anos 1990, o que se tem notícia é de praticamente tudo o que existe de escrito no Brasil sobre o índio, sobre os povos indígenas, sobre as culturas indígenas, não foi escrito por um índio. Foi sempre por um indigenista, por um antropólogo, por um sociólogo, por um estudioso, por um artista, por um poeta, por um escritor. Não que eu ache que isso seja uma coisa errada. Mas eu achava que, na medida em que nós nos tornássemos protagonistas das nossas próprias vozes, isso poderia gerar uma força muito grande, uma estratégia muito potente para se comunicar diretamente com a sociedade. E também para a sociedade ouvir diretamente a voz de um intelectual, de um cidadão, de um pensador, de um curador, de um contador de histórias vindo de um povo indígena (WERÁ, 2017, p. 25-26, destaques nossos). 
Destacamos, na primeira parte desse texto, que os povos indígenas se apropriaram e estilizaram a gramática formal, as técnicas literárias e as ferramentas digitais como forma de autoexpressão e de autoafirmação étnico-identitárias e, a partir disso, como meio de vinculação pública, política e cultural, em termos de ativismo, de militância e de engajamento. Por meio da escrita e a partir do uso de diferentes mídias e tecnologias de comunicação e de representação, passaram a divulgar não apenas suas tradições socioculturais, suas histórias e suas bases antropológico-ontológicas, mas também a nos relatar sobre sua situação de exclusão, de marginalização e de violência, passaram a nos contar sobre sua história e a partir de sua própria perspectiva. É assim que, primeiro, a literatura indígena funda e dinamiza um eu-nós lírico-político que parte de sua condição étnicoantropológica, de sua tradição, e se potencializa como crítica do presente, a partir do relato testemunhal, mnemônico e autobiográfico de sujeitos periferizados, oprimidos, jogados às margens de nossa modernização conservadora e produzidos por ela; segundo e como consequência, a literatura indígena permite a promoção do movimento indígena, constrói hegemonia político-cultural em torno a ele, sobre a questão indígena e, em tudo isso, leva ao protagonismo indígena, à desconstrução, por meio desse/a indígena militante, da história deturpada que sobre ele/ela foi construída. É aqui que pode ser situada essa intenção, muito própria aos/às escritores/as indígenas, de falar diretamente à sociedade, de, por meio da voz-práxis estético-literária militante, construir e dinamizar sua cidadania política. É aqui, por fim, que a imbricação entre movimento indígena e literatura indígena encontra seu sentido, ou seja, sob a forma de ativismo, de militância e de engajamento na esfera público-política, como sujeito públicopolítico que se vincula socialmente e que busca construir hegemonia cultural. Conforme Ailton Krenak, é por causa desse ativismo primeiramente da União das Nações Indígenas (UNI) e, depois, em sua ligação com a literatura indígena - que os povos indígenas brasileiros se consolidaram pública, política e culturalmente, saindo de uma situação de invisibilização, de silenciamento e de exclusão diretamente para a esfera público-política. Ele diz, de modo muito enfático, acerca de ambos os movimentos: 
A UNI iniciou a sua articulação mais permanente em 1979. Hoje, o Brasil sabe que existe o povo indígena. Acho que vocês sabem que, na década de 1960 e até o começo da década de 1970, mesmo as pessoas mais bem-informadas do Brasil, se perguntassem a elas sobre os índios, iam dizer: 'não, índio não. Não tem. Bem, talvez tenha um ou outro aí guardado em alguma reserva pelos irmãos Villas Boas". "Quem são os irmãos Villas Boas?", outro diria. "São heróis que têm lutado para guardar como relíquia alguns índios sobreviventes de 1500". Raoni (Metuktire, líder indígena caiapó) trouxe para o povo brasileiro e para o mundo cheiro de índio, cara de índio, impressão sobre o índio, expectativa. Em alguns casos, irritação, ódio, carinho, solidariedade. Nós provocamos sentimentos nas pessoas quando mostramos que éramos gente de verdade. Nós provocamos os fazendeiros. Nós provocamos o Conselho de Segurança Nacional, que botou os militares para nos vigiar mais de perto. Mas, em compensação, nós lembramos a milhares de pessoas que ainda estamos vivos e que queremos ser amigos dessas pessoas. $E$ isso é solidariedade. É uma palavra que não conhecíamos, mas uma ideia que praticamos há milhares de anos (KRENAK, 2015, p. 88).

Com o movimento indígena e, depois, também por meio da literatura indígena os povos, as lideranças, os/as escritores/as e os/as intelectuais indígenas assumem-se em cheio como uma questão público-política, como uma nova base cultural de nossa sociedade, como um novo sujeito político, institucional e cultural a dinamizar a sociedade brasileira em sua constituição e em sua evolução. E aqui se faz jus e se promove exatamente esse mote basilar a ambos, ao movimento indígena e à literatura indígena brasileiros, a saber, o falar e o agir diretamente, sem mediações institucionalistas, tecnicistas e cientificistas. Conforme pensamos, a literatura de minorias de um modo geral e a literatura indígena em particular promovem esse ativismo, essa militância e esse engajamento como o caminho e o instrumento por excelência de expressão pública, política e cultural, porque, no caso delas, não há alternativa, não há outra possibilidade de consolidação público-política que não o engajamento permanente e a politização radical. As minorias, as vítimas de nosso processo de modernização conservadora têm na práxis o caminho basilar de sua constituição, de 
sua emancipação, de sua resistência. É por isso que, na passagem acima, Ailton Krenak chamou a atenção para o fato de que o Brasil começou a conhecer os indígenas no momento em que estes indígenas assumiram-se como sujeitos, causa e condição público-políticos, no momento em que eles acessaram a esfera público-política e passaram a buscar, nela, a partir da práxis, hegemonia cultural. Essa presença das minorias, das vítimas de nossa modernização conservadora na esfera pública, como sujeitos público-políticos, desse modo, desnaturaliza, historiciza e politiza nossas estruturas sociais, culturais e institucionais, possibilitando interpretações renovadas e perspectivas práticas incisivas sobre o passado, o presente e o futuro de nossa sociedade. Foi isso que o movimento indígena e a literatura indígena construíram e consolidaram no Brasil contemporâneo:

O que eu acho é que muitas pessoas aqui estão incomodadas com que o mundo veja o Brasil na cara do Raoni. Porque o sinhozinho estava na sala tomando café, quando soube que alguém fugiu da senzala e foi fazer fuzarca. Ficou apavorado, chamou o capataz e perguntou: "mas o que é isso? Fugiu um negro da senzala; foi fazer confusão aí no mundo". Quem pode mostrar a cara lá fora é o sinhozinho. Ele sai da sala com gravata e paletó e vai se exibir no paraíso. Agora, pessoal da senzala, das malocas, não pode sair por aí se exibindo de tanga, botoque e cocar. O incomodo é tão grande para uma parte da elite brasileira que é mais ou menos como se vocês estivessem exibindo um segredo de família para o público. O Brasil está vendendo um retrato do branco para o mundo há 500 anos. De repente, quando ele mostra o pessoal que não é branco... (KRENAK, 2015, p. 96).

Note-se o jogo invisibilização, silenciamento, exclusão e privatismo versus ativismo, militância e engajamento públicos, políticos e culturais como a chave-de-leitura epistemológico-política para compreendermos o sentido do movimento indígena e da literatura indígena a ele vinculada. É a superação daqueles por meio destes que demarca e dinamiza ambos os movimentos construídos e realizados pelos indígenas, no Brasil contemporâneo. Com isso, nós podemos perceber $o$ quanto as lideranças e os/as intelectuais indígenas utilizaram-se e utilizam-se da literatura como veículo de politização de 
sua causa, de publicização dela junto à sociedade civil de um modo mais geral. Isso pode ser percebido no relato autobiográfico, testemunhal e mnemônico de Davi Kopenawa relativamente à situação dos povos Yanomami na região Norte do Brasil, que na década de 1970 foram atingidos em cheio pelos projetos de colonização, pelas atividades de garimpeiros e de mineradoras e pela abertura de estradas nesse contexto, com o objetivo de integrar esse vasto e bravio Norte, o grande deserto verde brasileiro, ao restante do país e em termos de uma política de desenvolvimento socioeconômico canalizada e orientada tecnocraticamente. Essa situação desagregou os povos Yanomami da região, sob a forma de doenças e epidemias, de morticínio advindo da invasão de suas terras por garimpeiros e mineradoras, de desmatamento e de expulsão de suas terras. Ora, foi para denunciar essa situação que Davi Kopenawa e Bruce Albert escreveram $A$ queda do céu: palavras de um xamã yanomami, o que mostra a politização da literatura indígena. Vejamos uma dessas passagens presentes no livro, relativamente a esses projetos de integração e de desenvolvimento na Amazônia, levados a efeito pelos governos militares. O caso em questão refere-se à abertura da Estrada Perimetral Norte, que passava diretamente nas terras Yanomami e consiste, como mencionamos acima, em um relato autobiográfico desse contato, experienciado pelo próprio Davi Kopenawa Yanomami:

Quando eu era criança, os brancos subiram os rios e começaram a fazer morrer nossos antigos em grande número. Depois voltaram, de avião e de helicóptero. Então suas fumaças de epidemia, mais uma vez, fizeram morrer muitos de nós. Agora, eles tinham resolvido abrir uma de suas estradas até o meio de nossa floresta, e suas doenças iriam com certeza devorar os que tinham sobrevivido. Eu ficava pensando em tudo isso, quando estava sozinho no posto da FUNAI. Isso me atormentava e me entristecia. Dizia a mim mesmo: "Os brancos rasgam a terra da nossa floresta. Derrubam as árvores e explodem as colinas. Afugentam a caça. Será que agora vamos todos morrer das fumaças de epidemia de suas máquinas e bombas?". Eu já sabia que essa estrada só iria nos trazer coisas ruins. Ninguém nos tinha avisado antes de as obras começarem. Chico só tinha dito umas poucas palavras a respeito para a gente de Werihisihipi $u$, quando abrimos o posto de Mapulaú. Eu tinha tentado 
alertá-los contra as doenças que iriam, mais uma vez, se espalhar pela nossa floresta. Porém, pouco depois eu iria embora para Manaus, devido à minha briga com Chico. No caminho, vi apenas o desmatamento do traçado da estrada, que tinha começado. Havia por toda parte grupos de brancos, com roupas rasgadas trabalhando com machados. As máquinas grandes ainda não tinham chegado (KOPENAWA; ALBERT, 2015, p. 305-306).

Os indígenas não foram consultados sobre esses projetos, naturalmente, e, conforme podemos perceber na obra Os fuzis e as flechas, de Rubens Valente, o ideário militar falava da Amazônia como o grande deserto verde que precisava ser colonizado e modernizado, sem qualquer citação mínima relativamente aos indígenas, como se ela contivesse somente árvores, animais e minérios7. Mas a constituição e o protagonismo do movimento indígena brasileiro, aliados ao desenvolvimento e à politização da literatura indígena, levaram a que os indígenas falassem sobre si, a partir de si mesmos e, em consequência, a que a sociedade brasileira os conhecesse e deles falasse, bem ou mal, mas agora com o próprio protagonismo do movimento, das lideranças e dos/as intelectuais indígenas como contraponto para quaisquer discursos e práticas caricatos, extemporâneos e preconceituosos em relação a eles. Ao longo do texto, procuramos exatamente relacionar a ditadura militar e o surgimento e o ativismo do movimento Indígena brasileiro e, depois, esse mesmo movimento e a literatura indígena que se desenvolve no Brasil a partir de 1990. O que se viu nisso tudo é a politização e a vinculação pública e cultural dos indígenas, em um movimento que enquadra, confronta e politiza nossa modernização conservadora. O resultado está aí: já não é mais possível a unidimensionalidade e a despolitização da esfera público-política, porque ela é plural, não mais concentrada, política e politizante, não mais (apenas) massificadora.

\footnotetext{
${ }^{7}$ Veja-se, acerca disso, a excelente passagem de Os fuzis e as flechas, de Rubens Valente: "Após o golpe de 1964, os militares retomaram antigas ideias de 'ocupação' da Amazônia, muitas vezes sem deixar claro qual seria o papel do índio nesse cenário. Em sua Geopolítica do Brasil, escrita nos anos 1960, o general Golbery do Couto e Silva, um dos protagonistas do golpe de 1964 e criador do SNI, definia a larga porção 'a oeste', incluindo a Amazônia - que chamou de 'deserto verde' -, como 'o simples domínio, o Brasil marginal, inexplorado em sua maior parte, desvitalizado pela falta de gente e de energia criadora, e o qual nos cumpre incorporar realmente à nação"” (VALENTE, 2017, p. 25).
} 


\section{Considerações finais}

Procuramos correlacionar, no texto, movimento indígena e literatura indígena brasileiros enquanto forma de superação do silenciamento, da invisibilização e do privatismo a que os povos indígenas, suas lideranças e seus/suas intelectuais foram submetidos política, cultural e institucionalmente em nossa história e, em particular, ao longo da ditadura militar. Mostramos, a partir de passagens (algumas delas bem extensas) de obras produzidas por essas lideranças e esses/essas escritores/as indígenas, o quanto o movimento indígena e a literatura indígena, em profunda intersecção e sob a forma de mútuo suporte, consolidaram o ativismo, a militância e o engajamento dos indígenas na esfera pública, política e cultural, a partir de uma perspectiva de crítica em relação à nossa modernização conservadora, de participação e de inclusão democráticas e de pluralismo axiológico. Essa correlação entre ambos e o engajamento dali resultante representam um momento exemplar de construção e de dinamização teórico-políticas em que um grupo marginalizado assume sua politicidade-politização, constrói sua cidadania política e reestiliza as práticas e as ferramentas simbólicas da modernidade em prol de sua autoexpressão e autoafirmação e, a partir dali, em termos de crítica do presente, de resistência cultural e de luta política. A partir de seu ativismo e tomando conhecimento de sua voz-práxis, vendo e lendo diretamente seus relatos, somos apresentados a um Brasil alternativo, que não conhecíamos, que nos era escondido e, portanto, confrontamos nossa despolitização acerca dele. Vendo e lendo diretamente suas produções, somos reeducados pelas vítimas de nossa modernização conservadora, vítimas que se tornaram sujeitos de sua e da nossa emancipação!

\section{Referências bibliográficas}

KRENAK, Ailton. Coleção Encontros. Organização Sérgio Cohn. Rio de Janeiro, 2015. 
KRENAK, Ailton. Ailton Krenak. Organização Kaká Werá. Rio de Janeiro: Azougue Editorial, 2017. Coleção Tembetá.

ALMEIDA, Maria Inês de; QUEIROZ, Sônia. Na captura da voz: as edições da narrativa oral no Brasil. Belo Horizonte: Autêntica; FALE/UFMG, 2004.

TUKANO, Alvaro. Álvaro Tukano. Organização de Sérgio Cohn e de Idjahure Kadiwel. Rio de Janeiro: Azougue Editorial, 2017, Coleção Tembetá.

BEHR, Héloïse. A emergência de novas vozes brasileiras: uma introdução à literatura indígena no Brasil. In: MELLO, Ana Maria Lisboa de; PENJON, Jacqueline; BOAVENTURA, Maria Eugenia. Momentos da ficção brasileira. Porto Alegre: EDIPUCRS, 2017. p. 259-279.

BRASIL. Constituição (1988). Constituição da República Federativa do Brasil. Brasília: Senado Federal/Centro Gráfico, 1988.

BRASIL. Lei 11.645/08 de 10 de Março de 2008. Diário Oficial da União, Poder Executivo, Brasília, 2008.

GRAÚNA, Graça. Contrapontos da literatura indígena contemporânea no Brasil. Belo Horizonte: Mazza Edições, 2013.

KOPENAWA, Davi; ALBERT, Bruce. A queda do céu: palavras de um xamã yanomami. São Paulo: Companhia das Letras, 2015.

MEDEIROS, Sérgio Luiz Rodrigues. Ainda não se pode ler em Xavante. In: MEDEIROS, Sérgio; DINIZ, Alai Garcia (Org.). NELOOLL. Florianópolis: NELOOL (UFSC), 2006, v. 1, p. 1-6.

MUNDURUKU, Daniel. O caráter educativo do movimento indígena brasileiro (1970-1990). São Paulo: Paulinas, 2012.

MUNDURUKU, Daniel. Memórias de índio: uma quase autobiografia. Porto Alegre: EDELBRA, 2016.

MUNDURUKU, Daniel. Mundurukando2: sobre vivências, piolhos e afetos: roda de conversa com educadores. São Paulo: UK’A Editorial, 2017.

THIÉL, Janice. Pele silenciosa, pele sonora: a literatura indígena em destaque. Belo Horizonte: Autêntica Editora, 2012.

VALENTE, Rubens. Os fuzis e as flechas: história de sangue e de resistência indígena na ditadura. São Paulo: Companhia das Letras, 2017.

WERÁ, Kaká. Kaká Werá. Organização de Sérgio Cohn e de Idjahure Kadiwel. Rio de Janeiro: Azougue Editorial, 2017. Coleção Tembetá. 
Espaço Ameríndio

Recebido em: 31/05/2018 * Aprovado em: 01/10/2018 * Publicado em: 29/12/2018 